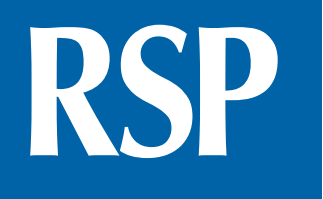

http://www.rsp.fsp.usp.br/
Revista de Saúde Pública

\title{
Healthcare telemonitoring and business dynamics: challenges and opportunities for SUS
}

\author{
Antonio da Cruz Paula' iD, José Manuel Santos de Varge Maldonado" iD, Carlos Augusto \\ Grabois Gadelha" \\ ' Grupo de pesquisa cadastrado no Cnpq: apoio à gestão de tecnologia, inovações e produtos estratégicos para \\ o Sistema de Saúde. \\ " Fundação Oswaldo Cruz. Escola Nacional de Saúde Pública Sérgio Arouca. Rio de Janeiro, RJ, Brasil
}

Correspondence:

Antonio da Cruz Paula

Travessa Cacilda Rodrigues, 218

21011-390 Rio de Janeiro, RJ, Brasil

E-mail: antonio.cruzpaula@gmail.com

Received: Aug 8, 2019

Approved: Dec 4, 2019

How to cite: Cruz A, Maldonado JMSV, Gadelha CAG.

Telemonitoring and business dynamics in health: challenges

and opportunities for the Brazilian Unified Health System. Rev Saude Publica. 2020;54:65.

Copyright: This is an open-access article distributed under the terms of the Creative Commons Attribution License, which permits unrestricted use, distribution, and reproduction in any medium, provided that the original author and source are credited.

\section{ABSTRACT}

OBJECTIVE: To point out challenges and opportunities for the Brazilian Unified Health System (SUS) with the use of telemonitoring to face the increasing costs of non-communicable chronic diseases, based on its general panorama in Brazil, business dynamics and reapplication of data from American studies.

METHODS: Quali-quantitative approach with exploratory research. The field work focused on the analysis of the national market from private companies, since no experiences or studies related to this theme were identified in the SUS. To analyze the panorama and market dynamics, we investigated the offer of this technology based on the products and services available and their demand by reference hospitals the ten largest private health plan companies. To support the central discussion, we analyzed the reduction of costs with hospital admissions by the SUS due to chronic non-communicable diseases sensitive to telemonitoring (HCDST), using data from Datasus and some American studies from the MEDLINE/PubMed database.

RESULTS: Although in the embryonic phase, business agents search for new business opportunities, whereas public initiatives for the use of telemonitoring in collective health seem inexistent. The reapplication of U.S. data would reduce spending on HCDST and provide benefits, such as the reduction in emergency room care, acute hospitalizations, readmissions and home care time, among others, which point to even greater economic gains.

CONCLUSIONS: The development of a major project to reduce HCDST using this technology has the potential to advance in a comprehensive network of primary care, contribute to a greater dynamism of the national productive and innovative base and induce innovations along the chain of this emerging industry.

DESCRIPTORS: Noncommunicable Diseases, prevention \& control. Telemonitoring. Health Care Sector. 


\section{INTRODUCTION}

Telemonitoring is one of the most important applications of telemedicine, characterized by telemonitoring of health data of a patient by a specialized center for monitoring, interpretation and analysis. Dehospitalization, preventive health, early diagnosis, increased life expectancy, better comfort and increased worked hours are among the benefits of this technology. It has been considered important to address the growth in the costs of chronic non-communicable diseases (CNCD) by the national health systems, one of the main problems in the provision of health services worldwide ${ }^{1-3}$.

CNCD are a global concern, impacting the goals established in the Millennium Development Goals, as they are responsible for the main causes of death in the world, with repercussions on the loss of quality of life and limitation of work and leisure, as well as on the economic impacts for families and health systems. Therefore, the United Nations (UN) has instructed countries to develop action plans for their prevention and control ${ }^{4,5}$.

Primary health care plays an important role in their prevention and control, since some CNCD are preventable by conditions sensitive to primary care ${ }^{6,7}$. Therefore, countries seek different approaches, among which telemonitoring has stood out as an important alternative.

Brazil faces significant challenges in the construction of the Unified Health System (SUS) due to the country's continental dimensions and population of more than 200 million people, which hinders the compliance with the constitutional precept of health universalization. Moreover, the complex demographic and epidemiological transitions imply greater efforts that impact the health budget. The increase in CNCD accounts for $75 \%$ of SUS expenses and $72 \%$ of deaths, of which $31.3 \%$ are due to diseases of the circulatory system, $16.3 \%$ of cancer, $5.2 \%$ of diabetes and $5.8 \%$ of respiratory diseases, being the four most representative groups $s^{4,8}$.

Despite the experiences and important studies from the Telehealth Network Program (Telehealth), the scientific production in the specific field of telemonitoring that seeks to demonstrate the benefits arising from its use is insufficient, which includes the analysis of costs, given its undeniable importance for public and private health systems ${ }^{7,9-11}$. One example is a recent study conducted in Brazil with older adults in chronic condition, which pointed out a positive relationship between the use of telemonitoring and adherence to drug treatment ${ }^{12}$.

However, we observed a development and offer of solutions for the Brazilian market, which shows the interest and expectation of business agents in the growth of demand, whereas public policies, in turn, are scarce in this area. This fact points to the need for greater participation of the State, given the risk of the opportunities opened by telemonitoring being appropriated exclusively by business strategies.

Thus, the objective of this article is to identify the challenges and opportunities for the SUS due to the use of telemonitoring, based on business and institutional dynamics and economic benefits.

\section{METHODS}

Our study fits into the qualitative-quantitative approach with exploratory research. A literature review allowed a qualitative analysis with developments in the quantitative approach to estimate the cost reduction with the use of telemonitoring by the SUS ${ }^{13}$.

Within the Scope of the SUS, no experiences or studies related to this theme were identified in the search in the SciELO, Capes and Google Scholar databases, as well as in the analysis of projects between 2009 and 2020 of the SUS Institutional Development Support Program 
(Proadi) $^{14}$. Therefore, the fieldwork focused on the analysis of the national market from private companies.

Regarding the offer, a survey was conducted to identify companies that sell specialized services and telemonitoring products in the Brazilian market, based on searches in the Google search with the descriptors "remote health monitoring," "health management," "homecare" and "health teleassistance," while suppliers of products were identified among the exhibiting companies in the largest fair of hospital equipment in Brazil in $2017^{15}$.

Regarding the demand, we opted for the reference hospitals recognized by the Brazilian Ministry of Health (MS) in the triennium of 2018-2020, i.e., the Health Entities of Recognized Excellence (HERE), and the ten largest private health plan companies were selected, which establish a competitive modus operandi $i^{16,17}$.

To support the central discussion, we analyzed the reduction of costs with hospital admissions by the SUS due to CNCD most impacted by telemonitoring (cardiovascular and respiratory diseases, and diabetes), hereinafter "hospitalizations for chronic diseases sensitive to telemonitoring (HCDST)," a subgroup of hospitalizations due to CNCD (HCNCD), a category already existing and monitored by the $\mathrm{MS}^{1,4,18}$. Datasus and some studies from the MEDLINE/PubMed database, identified by the descriptors "telemedicine," "telehealth" and "ehealth" associated with the terms "economic benefit monitoring" and "remote patient monitoring" were also used. Finally, the calculations of cost reduction with HCDST were obtained from the replicability of the most conservative data from these studies.

\section{RESULTS}

We present a framework of telemonitoring in Brazil with data from the main policy initiatives, regulatory issues and the national market, as well as some estimates of economic benefits for the SUS with the use of telemonitoring.

\section{Telemonitoring Framework in Brazil}

There are few actions to expand its use in Brazil, especially by the SUS, despite the immense benefits pointed out by specialists and the evolution of telemedicine in the country in recent years, resulting from incentives of research promotion agencies and important government actions that resulted in the formation of infrastructure, teams and research centers in several academic institutions in the country. Regarding public policies, it can be said that in Brazil there were some initiatives that culminated essentially in the projects University Telemedicine Network (Rute) and Telehealth, both with a focus on telemedicine to support and improve the quality of Primary Health Care ${ }^{9,10}$.

Currently, Telehealth is implemented in all states of the country and is an important instrument of innovation for the Family Health Program (FHP). Despite the emphasis given in some states, such as the remote electrocardiogram service developed in the state of Minas Gerais, teleradiography (TeleRX) in Rio de Janeiro, telediagnosis for chronic respiratory diseases and obstetric ultrasounds in Rio Grande do Sul and teleducation in São Paulo, among others, national actions in the field of telemonitoring are not identified.

However, although the Strategic Action Plan for Coping with CNCD in the MS provides for the use of telemonitoring, and studies point to its benefits, there are no initiatives in the field of public health policies in Brazil, as well as formal studies of the Ministry of Health for an analysis of its cost-benefit, although several other countries, such as members of the European Union (EU), have this application as one of the main focuses in the strategy to combat the problems arising from this group of diseases ${ }^{4,19}$. 
Regarding regulatory aspects, there is a wide variety in the positioning of federal councils regarding the use of telemedicine by professionals and service providers. Some councils have a liberal position, but no regulations for the provision of distance services, such as those of physical education and social services; there are others with significant flexibility, such as those of psychology and nursing; and some others are still very reactive, such as the councils of physiotherapy, nutrition and medicine ${ }^{20-26}$. Unlike other applications of telemedicine, Telemonitoring has no explicit regulatory restriction in different health specializations.

The case of the Federal Council of Medicine (FCM) deserves a more detailed analysis. With resolution no. 2,227 of 2018 published in February 2019, the FCM expanded the attributions of telemedicine, enabling distance medical services vis-à-vis, that is, teleconsultation. However, the FCM opted to postpone its entry into force due to the numerous criticisms from physicians, representative entities and regional councils, especially regarding the insufficient participation in the drafting of this resolution, the early release by some private companies of new services based on teleconsultation, prohibited until then by resolution No. 1,643 of 2002 .

Although this discussion has as its central element the teleconsultation, it is reflected in telemonitoring regarding private initiative, for its responsiveness, based on the perspective of occupation of this market with the offer of integrated service packages. This point was illustrated the anticipation of announcement of teleconsultation by the hospital Albert Einstein in early February 2019. In the field of public health, in turn, regulatory decisions that do not involve all stakeholders with extensive discussions and reflections on their impacts may distort comprehensive care projects and further weaken the SUS.

Specialized services and products are offered for the national market, as well as a wide variety of devices, which indicates a potential for the commercialization of this technology in the country. Chart 1 shows companies in Brazil that offer specialized services and products within the scope of telemonitoring, the federative unit in which they are located, their application and customers ${ }^{4,11}$.

There is diversity regarding the modality of providing specialized services, such as homecare, health management and telemonitoring service providers for older adults. As for the technologies used, the use of telephone, wearables or smart clothing such as electronic bracelets, as well as the application of artificial intelligence and big data for predictive analysis and health management.

Regarding the products, we observed, in the market, an offer of solutions aligned with the main strategies pointed out by the literature for their use by patients with CNCD: education or self-care, telecare and management or monitoring. However, the main consumer market is retail, which indicates that service providers have not yet adopted telemonitoring as a tool. On the other hand, it is a sign that their acceptance by the end user grows. These first movements of the private sector signal prospects for market growth, in which new business opportunities, service expansion and increased health costs due to CNCD, among other factors, help explain the growing interest in this emerging industry. Despite the dissemination of studies in other countries that point to positive impacts of its use regarding the improvement in quality of life and cost reduction in the provision of health services to patients with CNCD, some initiatives of private companies in this area focus mainly on telemonitoring without the use of innovative technologies that would allow remote telemonitoring in real time.

Chart 2 shows the most important private health service providers in the country, which have developed initiatives for health prevention and management in their businesses, with the perspective of improving the quality of life and self-care of patients, especially of chronic patients, albeit with different objectives. Hospitals bet on the development of a new market, preventive medicine, for which they built structures with multidisciplinary teams and 
Chart 1. Companies providing specialized services and telemonitoring products: field survey.

\begin{tabular}{|c|c|c|c|c|c|}
\hline \multirow{2}{*}{ Websites } & \multicolumn{5}{|c|}{ Specialized service providers } \\
\hline & Company & State & Product/services & Application & Customers \\
\hline $\begin{array}{l}\text { http://www.ocuidadorvirtual. } \\
\text { com.br/ }\end{array}$ & 24/7 Care & SP & $\begin{array}{l}\text { Teleassistance in general, } \\
\text { medical guidance at a distance } \\
\text { and ambulance call }\end{array}$ & $\begin{array}{l}\text { Electronic bracelet with alarm } \\
\text { button for care of older adults }\end{array}$ & Retail market \\
\hline https://www.athoscare.com.br/ & Athoscare & SP & $\begin{array}{l}\text { Home care service with basic } \\
\text { telemonitoring (by phone) }\end{array}$ & $\begin{array}{l}\text { Patients with diabetes, hypertension } \\
\text { and Alzheimer's, either bedridden } \\
\text { or with some difficulties }\end{array}$ & Retail market \\
\hline http://lincare.com.br/ & Lincare & MG & $\begin{array}{l}\text { Remote cell phone monitoring } \\
\text { for older adults }\end{array}$ & $\begin{array}{l}\text { Electronic wristband for measuring } \\
\text { sleep, heart rate, blood pressure } \\
\text { and steps/distance covered }\end{array}$ & Retail market \\
\hline https://qualirede.com.br/ & Qualirede & SC & $\begin{array}{l}\text { Specialized in health insurance } \\
\text { management }\end{array}$ & $\begin{array}{c}\text { Artificial intelligence, data } \\
\text { analytics, data science and } \\
\text { predictive analysis - health } \\
\text { management of } 65,000 \text { chronic } \\
\text { patients }\end{array}$ & Corporate market \\
\hline http://www.telehelp.com.br/ & Tele Help & SP & $\begin{array}{l}\text { Teleassistance in general, } \\
\text { medical guidance at a distance } \\
\text { and ambulance call }\end{array}$ & $\begin{array}{l}\text { Electronic bracelet with alarm } \\
\text { button for care of older adults }\end{array}$ & Retail market \\
\hline \multirow[t]{15}{*}{ http://unicaresaude.com.br/ } & $\begin{array}{l}\text { Unicare } \\
\text { Saúde }\end{array}$ & SP & $\begin{array}{l}\text { Service provider in the segment } \\
\text { of high complexity home care }\end{array}$ & Uses the i9Access solution & $\begin{array}{l}\text { Health plan } \\
\text { operators and retail } \\
\text { market }\end{array}$ \\
\hline & \multicolumn{5}{|c|}{ Product suppliers } \\
\hline & Company & State & Service & Application & Focus \\
\hline & Apple & Global & Saúde app and Apple Watch & $\begin{array}{c}\text { Preventive health with a focus } \\
\text { on encouraging and controlling } \\
\text { food, physical activities, sleep and } \\
\text { relaxation activities }\end{array}$ & $\begin{array}{l}\text { Retail market - users } \\
\text { of smartphones }\end{array}$ \\
\hline & Bioaps & SP & $\begin{array}{c}\text { PRM - Patient Relantionship } \\
\text { Management }\end{array}$ & User empowerment and prevention & $\begin{array}{l}61,000 \text { patients at } \\
\text { the health insurance } \\
\text { company São } \\
\text { Francisco }\end{array}$ \\
\hline & Cisco/Nexa & Global & SmartCare & $\begin{array}{l}\text { Concept of collaboration platform } \\
\text { with a call center that encourages } \\
\text { the adoption of healthy habits, } \\
\text { compliance with prescriptions and } \\
\text { monitors the health conditions } \\
\text { of customers }\end{array}$ & $\begin{array}{l}\text { Hospitals, clinics } \\
\text { and health } \\
\text { professionals }\end{array}$ \\
\hline & Fitbit & Global & Fitbit Smart Bracelets & $\begin{array}{l}\text { Physical activity monitoring } \\
\text { bracelets }\end{array}$ & Retail market \\
\hline & i9Access & RS & $\begin{array}{c}\text { Telemonitoring management } \\
\text { system }\end{array}$ & Telemonitoring and empowerment & $\begin{array}{l}\text { Unicare Saúde - } \\
\text { home care service } \\
\text { provider }\end{array}$ \\
\hline & Lifemed & SP & $\begin{array}{l}\text { Central Lifeview capable of } \\
\text { monitoring vital signs for up to } \\
32 \text { patients }\end{array}$ & $\begin{array}{l}\text { Tele-homecare, preventive health } \\
\text { and CNCD }\end{array}$ & $\begin{array}{l}\text { Hospitals, clinics } \\
\text { and health } \\
\text { professionals }\end{array}$ \\
\hline & Mcare & RJ & $\begin{array}{l}\text { Mobile system-based } \\
\text { telemonitoring system }\end{array}$ & $\begin{array}{c}\text { Obtains and manages device } \\
\text { data via Bluetooth, passing on to } \\
\text { healthcare professionals by email, } \\
\text { voice, or text }\end{array}$ & $\begin{array}{l}\text { Hospitals, clinics } \\
\text { and health } \\
\text { professionals }\end{array}$ \\
\hline & Philips & Global & $\begin{array}{l}\text { IntelliVne patient monitoring } \\
\text { center }\end{array}$ & $\begin{array}{c}\text { Remote access to patient } \\
\text { information for support in critical } \\
\text { decisions }\end{array}$ & $\begin{array}{l}\text { Hospitals, clinics } \\
\text { and health } \\
\text { professionals }\end{array}$ \\
\hline & Signove & PB & $\begin{array}{c}\text { Sig Health platform, a } \\
\text { telemonitoring system } \\
\text { integrated with various devices }\end{array}$ & $\begin{array}{l}\text { Tele-homecare, preventive health } \\
\text { and CNCD }\end{array}$ & $\begin{array}{l}\text { Hospitals, clinics } \\
\text { and health } \\
\text { professionals }\end{array}$ \\
\hline & Samsung & Global & S Health app & $\begin{array}{c}\text { Preventive health with a focus } \\
\text { on encouraging and controlling } \\
\text { food, physical activities, sleep and } \\
\text { relaxation activities }\end{array}$ & $\begin{array}{l}\text { Retail market } \\
\text { - Samsung } \\
\text { smartphone users }\end{array}$ \\
\hline & Ventrix & SP & Telemedicine systems & $\begin{array}{c}\text { Telemonitoring of babies and } \\
\text { tele-ECG }\end{array}$ & $\begin{array}{l}\text { Retail market } \\
\text { and healthcare } \\
\text { professionals }\end{array}$ \\
\hline & Xiaomi & Global & Smart watches & $\begin{array}{l}\text { Smart watches for monitoring } \\
\text { physical activity }\end{array}$ & Retail market \\
\hline
\end{tabular}

Source: Own elaboration based on Hospitalar ${ }^{15}$, Maldonado, Marques and Cruz $^{11}$ and institutional websites of the companies. 
Chart 2. Main initiatives of private service providers.

\begin{tabular}{|c|c|c|c|c|}
\hline \multicolumn{5}{|c|}{ Reference hospitals } \\
\hline Company & State & Service & Application & Focus \\
\hline Albert Einstein ${ }^{\mathrm{a}}$ & SP & $\begin{array}{c}\text { Tele babycare, telecessação do } \\
\text { tabagismo, Einstein em movimento } \\
\text { and bem estar Einstein }\end{array}$ & $\begin{array}{l}\text { Babies, smokers, guided physical } \\
\text { activities, positive psychology }\end{array}$ & $\begin{array}{l}\text { Self-care as a result of the sale of check- } \\
\text { up and preventive examinations }\end{array}$ \\
\hline Albert Einstein ${ }^{\mathrm{a}}$ & SP & Teleconsulta & $\begin{array}{l}\text { Companies, patients and other health } \\
\text { care providers }\end{array}$ & $\begin{array}{l}\text { Creation of new integrated service } \\
\text { packages and market expansion }\end{array}$ \\
\hline Sírio Libanês & SP & Health monitoring and check up & $\begin{array}{l}\text { Preventive medicine and chronic } \\
\text { patients }\end{array}$ & $\begin{array}{l}\text { Self-care as a result of the sale of check- } \\
\text { up and preventive examinations }\end{array}$ \\
\hline $\begin{array}{l}\text { Hospital do } \\
\text { Coração }\end{array}$ & SP & $\begin{array}{c}\text { Check-up program for } \\
\text { teleconsultation and telediagnosis } \\
\text { for SUS's patients }\end{array}$ & $\begin{array}{l}\text { Preventive medicine and chronic } \\
\text { patients }\end{array}$ & $\begin{array}{l}\text { Self-care as a result of the sale of } \\
\text { check-up and preventive examinations } \\
\text { to customers - new business with } \\
\text { telemedicine services for SUS and other } \\
\text { hospitals }\end{array}$ \\
\hline $\begin{array}{l}\text { Hospital Alemão } \\
\text { Oswaldo Cruz }\end{array}$ & SP & Care model & Preventive medicine & $\begin{array}{l}\text { Self-care as a result of the sale of check- } \\
\text { up and preventive examinations }\end{array}$ \\
\hline \multicolumn{5}{|c|}{ Insurers and operators of private health plans } \\
\hline Company & State & Service & Application & Focus \\
\hline Amil & National & $\begin{array}{l}\text { High-risk patient management and } \\
\text { family health strategy }\end{array}$ & $\begin{array}{l}\text { Chronic patient monitoring, single } \\
\text { gateway for patients with FHS and } \\
\text { incentive to self-care }\end{array}$ & $\begin{array}{l}\text { Improving quality of life and reducing } \\
\text { costs with beneficiaries }\end{array}$ \\
\hline Bradesco Saúde & National & Juntos pela saúde & $\begin{array}{l}\text { Monitoring of chronic and anti- } \\
\text { smoking patients }\end{array}$ & $\begin{array}{l}\text { Improving quality of life and reducing } \\
\text { costs with beneficiaries }\end{array}$ \\
\hline Cassi & National & Estratégia da família & $\begin{array}{c}\text { Health promotion and disease } \\
\text { prevention }\end{array}$ & $\begin{array}{l}\text { Rational use of the network of accredited } \\
\text { and specialized services }\end{array}$ \\
\hline Hapvida & Northeast & HapPrev and Viva Leve Programs & $\begin{array}{l}\text { Preventive medicine, self-care and } \\
\text { continuous monitoring of HapPrev } \\
\text { participants - chronic education and } \\
\text { monitoring with Viva Leve. }\end{array}$ & $\begin{array}{l}\text { Improving quality of life and reducing } \\
\text { costs with beneficiaries }\end{array}$ \\
\hline Intermedica & National & $\begin{array}{l}\text { Support for patients with chronic } \\
\text { diseases }\end{array}$ & Proactive monitoring and self-care & $\begin{array}{l}\text { Improving quality of life and reducing } \\
\text { costs with beneficiaries }\end{array}$ \\
\hline Nacional Unimed & National & $\begin{array}{c}\text { Comprehensive health care } \\
\text { strategy and health management } \\
\text { program }\end{array}$ & $\begin{array}{l}\text { Self-care and self-care engagement } \\
\text { monitoring for chronic patients }\end{array}$ & $\begin{array}{l}\text { Improving quality of life and reducing } \\
\text { costs with beneficiaries }\end{array}$ \\
\hline Sulamérica & National & $\begin{array}{l}\text { Saúde ativa program and } \\
\text { sharecare app }\end{array}$ & $\begin{array}{l}\text { Innovative technologies to monitor } \\
\text { health conditions and engage } \\
\text { beneficiaries in self-care activities }\end{array}$ & $\begin{array}{l}\text { Improving quality of life and reducing } \\
\text { costs with beneficiaries }\end{array}$ \\
\hline Unimed $\mathrm{BH}$ & MG & $\begin{array}{l}\text { Health promotion centers and } \\
\text { health care program }\end{array}$ & $\begin{array}{l}\text { Self-care and monitoring of chronic } \\
\text { patients }\end{array}$ & $\begin{array}{l}\text { Improving quality of life and reducing } \\
\text { costs with beneficiaries }\end{array}$ \\
\hline Unimed-Poa & RS & Viver bem program & $\begin{array}{c}\text { Interactive channel with information } \\
\text { on improving quality of life for } \\
\text { different groups, including chronic } \\
\text { patients }\end{array}$ & $\begin{array}{l}\text { Improving quality of life and reducing } \\
\text { costs with beneficiaries }\end{array}$ \\
\hline Unimed-Rio & RJ & $\begin{array}{l}\text { Health promotion and disease } \\
\text { risk prevention programs - } \\
\text { management of chronic diseases, } \\
\text { heart and pregnancy }\end{array}$ & $\begin{array}{c}\text { Self-care and monitoring of chronic } \\
\text { patients }\end{array}$ & $\begin{array}{l}\text { Improving quality of life and reducing } \\
\text { costs with beneficiaries }\end{array}$ \\
\hline $\begin{array}{l}\text { Unimed }^{b} \text { (Sta } \\
\text { Maria, RS) }\end{array}$ & RS & $\begin{array}{l}\text { Program for telemonitoring } \\
\text { chronic patients (by phone) }\end{array}$ & $\begin{array}{c}\text { Self-care and monitoring of chronic } \\
\text { patients }\end{array}$ & $\begin{array}{l}\text { Improving quality of life and reducing } \\
\text { costs with beneficiaries }\end{array}$ \\
\hline
\end{tabular}

Source: Own elaboration, based on the institutional websites of the companies.

a Two different strategies.

${ }^{\mathrm{b}}$ Unimed Santa Maria is not included among the largest health companies in the country; however, it was included in the universe of analysis as an example of an operator that uses telemonitoring.

equipment, having the commercialization of check-up exams as a central element. On the other hand, health insurers have similar structures for health prevention and management, aiming mainly at reducing costs.

Regarding the demand for the SUS, effective actions for the use of this technology are inexistent, despite FHP being a locus potential for the development of a broad project for remote patient monitoring, similarly to what happens with public policies. Finally, we observed that in this market, although in the embryonic phase, business agents search 
for new business opportunities, whereas initiatives for use by the SUS in collective health are apparently inexistent. This dichotomy can segment the provision of this service, leaving a significant part of the population at the mercy of the private payment logic.

\section{Challenges and Opportunities for SUS}

Despite the enormous benefits of telemonitoring, few studies seek to relate its use to an improvement of the sustainability of health systems.

Based on the replicability of the most conservative data available in MEDLINE/PubMed database studies, our research resulted in an estimate of HCDST costs by SUS. Thus, Figure shows the rates of hospitalization for chronic diseases in Brazil between 2000 and 2009, which support the estimation of HCDST and respective expenses for the year 2017.

\section{Cost Calculation for Telemonitoring Sensitive Hospitalizations in 2017}

Based on Figure, we can determine the total rate of HCNCD (Tx HCNCD) per 100,000 inhabitants:

Tx HCNCD $=$ cardiovascular diseases + cancer + diabetes + respiratory diseases $=600+$ $300+180+70=1,150$

In our study, considering that the HCDST are equal to the HCNCDT minus the hospitalizations for cancer, we can estimate the total rate of HCDST (Tx HCDST) per 100,000 inhabitants:

Tx HCDST $=$ Tx HCNCD - Tx cancer $=1,150-300=850$

With the HCDST rate, we can estimate the HCDST and its respective percentage in relation to the total number of hospitalizations (\% HCDST) in 2009:

$\mathrm{HCDST}=\left(\mathrm{Tx}\right.$ HCDST $\times$ population $\left.{ }^{27}\right) / 100,000=(850 \times 190,755,799) / 100,000=1,621,424$

$\%$ HCDST in relation to total hospitalizations $=1,621,424 / 9,011,304=18 \%$

In Brazil, the $\mathrm{MH}$ does not have historical series data available for the analysis of the SUS hospitalizations. However, the data available for the period between January 2017 and May 2017 provide important indications about the Brazilian problem ${ }^{28}$ : the total number of hospitalizations in 2017 was 3,952,133 in May, and 9,485,119 in December,

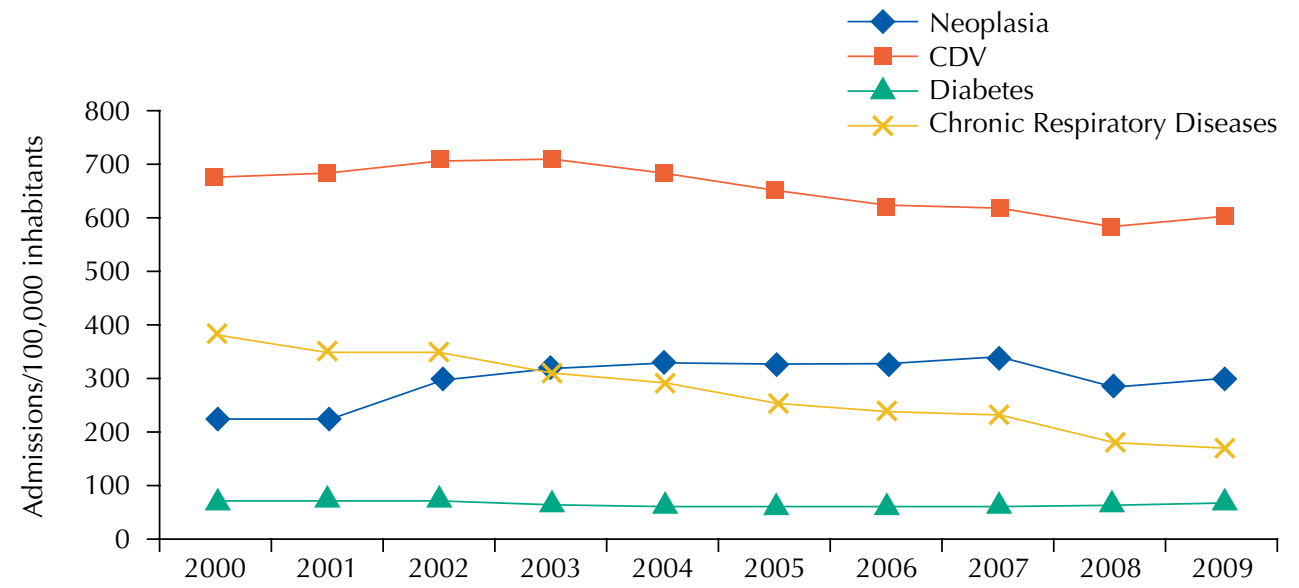

Source: Prepared by the Brazilian Ministry of Health4 (p. 43) based on data from the SUS Hospital Information System. CVD: Cardiovascular disease

Figure. Rate of hospitalization for selected chronic diseases in Brazil, 2000 to 2009. 
and the total cost of hospitalizations in 2017 was $\mathrm{R} \$ 4,549,734,441.63$ until May and $\mathrm{R} \$$ 10,919,362,659.91 until December.

Based on the aforementioned data and considering the percentage of HCDST (18\%) estimated for 2009, expenditures on hospitalizations per HCDST can be estimated for 2017 as follows: $10,919,362,659.91 \times 0.18=\mathrm{R} \$ 1,965,485,278.78$.

That is, the potential for cost reduction only with the use of telemonitoring for HCDST in 2017 is around $R \$ 2.0$ billion if aligned with a comprehensive primary care strategy in the SUS ${ }^{29}$. Since our study seeks not only the potential for cost reduction, but also an estimate of the economic benefits with the adoption for HCDST by the SUS, we show some MEDLINE/PubMed study results and analyze its replicability for the Brazilian situation.

One of the pioneers in these studies is the Veteran Health Administration (VHA), a program aimed at serving about 22 million American war veterans, which developed a pilot telemonitoring program with 900 patients between 2000 and 2003. The results show a $40 \%$ reduction in emergency care, a $63 \%$ decrease in hospital admissions, an $88 \%$ reduction in home care time and a satisfaction rate of around $90 \%$ in the period ${ }^{18}$.

Another study conducted between 2004 and 2007 that analyzed HCNCD and hospitalizations for mental health issues pointed drastic reductions in hospitalizations due to the use of telemonitoring: $56.4 \%$ in patients with depression, $45.1 \%$ in patients suffering from posttraumatic stress disorder, $40.9 \%$ in patients suffering from other mental health problems, $30.3 \%$ in patients with hypertension, $25.9 \%$ in patients with heart failure, $20.7 \%$ in patients with chronic obstructive pulmonary disease and $20.4 \%$ in patients with diabetes. Consequently, VHA's budget for telemedicine in 2017 increased to $\$ 1.2$ billion $^{30}$.

In two recent studies coordinated by the Maryland Health Care Commission (MHCC) involving telemonitoring, some data corroborate those found by VHA. The first analyzed the acute hospitalizations (in intensive care units) of 22 patients with CNCD at a cost of US\$ 66,000.00 for the entire program. The results showed a reduction of $66 \%$ in acute hospitalizations and from $15.7 \%$ to $4.5 \%$ in the rate of readmissions. Considering the cost of US\$10,352.00 of each hospitalization of the U.S. program Medicare, the estimated savings were US\$ 372,672.00, much higher than the cost to implement the entire program ${ }^{1}$. The second lasted 180 days and only analyzed the readmissions of 57 patients with CNCD at a cost of US\$60,000.00. The final report pointed to a reduction of 44 readmissions in the first 30 days of the program alone and an estimated savings of US\$ 308,000 , considering the cost of US\$ 7,000 per hospitalization ${ }^{2}$.

Therefore, the potential for reduction was around $\mathrm{R} \$ 2.0$ billion in HCDST due to telemonitoring for 2017 and the variation in the rate of reduction of HCDST among the three studies above (minimum of $25 \%$ in VHA and maximum of $66 \%$ in MHCC). Hence, we estimated that costs with HCDST in the SUS could be reduced between R $\$ 500$ million and $\mathrm{R} \$ 1.3$ billion per year with the replication of these experiences, without considering other benefits such as reductions in emergency room care, acute hospitalizations, readmissions and home care time, among others, which would point to an even greater economic gains.

\section{DISCUSSION}

The MEDLINE/PubMed studies presented in our article are in consistence and point to a significant reduction in HCDST costs when compared with the costs to implement and manage telemonitoring systems. The economic benefits estimated in our research consider only the reduction of costs of HCDST for SUS. However, other important benefits can be provided by the use of telemonitoring if associated with a structure that enables a comprehensive primary care network, such as reduction in the demand for consultations and emergencies, logistics costs, costs for inactive workers, etc., as well as other qualitative benefits, such as time to respond to disorders, comfort and transportation of patients. 
Retail companies are the main consumer market of specialized telemonitoring products and services, an indication that its acceptance and use by the end user grows, a result of behavioral changes in which people increasingly seek to monitor their health conditions preventively. These factors stimulate the use of telemonitoring by service providers as a powerful tool for health promotion, disease prevention, improvement of the quality of services and, especially, cost reduction. The use of this technology by large operators of private health plans, similar to global trends, will also be a major inducer for the growth of this market in the country.

Within the scope of business dynamics, solutions for the Brazilian market have been developed and offered, which demonstrates that business agents see interest and expect demand growth for these products. The interest of these business agents in this emerging market is reflected in the recent discussion on the expansion of the use of telemedicine promoted by the Federal Council of Medicine. The early launch of service packages over the private network signals both the game of interests involved and the strong pressures for greater regulatory flexibility. It also shows the tension between the private sphere, concerned with the opening of new markets, and the public sphere regarding patient safety, patient information security, doctor-patient relationship, quality or accuracy of diagnosis, among other ethical and legal aspects relevant to the practice of telemedicine. These aspects reinforce the need for a further discussion with broad participation and that contemplate the strengthening of public health in Brazil.

The country is lagging behind in telemedicine, especially in telemonitoring. Learning from other countries' experiences, obtaining up-to-date and georeferenced data on bed use (quantity, costs and occupancy rate by type of use) and analyzing regulatory restrictions and legal aspects, safety issues and technologies most appropriate to the Brazilian reality, as well as developing contingency plans, are examples of issues that must be further studied.

Within the Scope of the SUS, we observed caution regarding new advances. Considering that the main technologies that support telemonitoring solutions also form the structural basis of other telemedicine applications, the development of a major project to reduce HCDST has the potential to progress in the construction of a comprehensive primary care network, contribute to a greater dynamism of the national productive and innovative base and induce innovations throughout the chain of this emerging industry.

Our article shows the potential of this technology, with perspectives of significant cost reduction in the SUS only considering the HCDST. However, scientific production in the specific field of telemonitoring is still insufficient. Therefore, the challenges for government agencies, service providers, industry, educational and research institutions, among others, require joining forces for the development of new studies and customized solutions to the characteristics of a country of such a continental extension; solutions oriented simultaneously to the improvement of the sustainability of the SUS, advance in the provision of health services and development of the national industry and the economic-industrial complex of health, including regarding the services already offered by Telehealth, from the perspective of the political economy of the health.

\section{REFERENCES}

1. Maryland Health Care Commission. Remote Patient Monitoring Telehealth Grants: brief and final reports. Baltimore, MA: MHCC; 2017. Remote Patient Monitoring (RPM) Telehealth: Project Final Report - Lorien Health System (p.26-47). [cited 2018 Aug 30]. Available from: https://mhcc.maryland.gov/mhcc/pages/hit/hit_telemedicine/documents/Telehealth_Brief_ Reports_FINAL_031617.pdf.

2. Maryland Health Care Commission. Remote Patient Monitoring Telehealth Grants: brief and final reports. Maryland Health Care Commission. Baltimore, MD; 2017. Project Final Report - Union Hospital of Cecil County (p48-70). [cited 2018 Aug 30]. Available from: https://mhcc.maryland. gov/mhcc/pages/hit/hit_telemedicine/documents/Telehealth_Brief_Reports_FINAL_031617.pdf. 
3. Schadelbauer R. Anticipating economic returns of rural telehealth. Arlington, VA: NTCA-The Rural Broadband Association; 2017.

4. Ministério da Saúde (BR), Secretaria de Vigilância em Saúde, Departamento de Análise de Situação de Saúde. Plano de Ações Estratégicas para o Enfrentamento das Doenças Crônicas Não Transmissíveis (DCNT) no Brasil 2011-2022. Brasília, DF; 2011.

5. Organização das Nações Unidas. Resolução para a Prevenção e Controle das Doenças Não Transmissíveis. [cited 2017 Aug 16]. Available from: https://www.un.org/ga/search/view_doc.asp ?symbol=A\%2F64\%2FL.52\&Submit=Search\&Lang=E\%20 .

6. Afradique ME, Bonolo PF, Dourado I, Lima-Costa MF, Macinko J, Mendonça CS, et al. Internações por condições sensíveis à atenção primária: a construção da lista brasileira como ferramenta para medir o desempenho do sistema de saúde (Projeto ICSAP - Brasil). Cad Saude Publica. 2009;25(6):1337-49. https://doi.org/10.1590/S0102-311X2009000600016

7. Castro Filho EDC. Telessaúde no apoio a médicos de atenção primária [tese]. Porto Alegre: Faculdade de Medicina da Universidade Federal do Rio Grande do Sul; 2011 [cited 2019 Nov 27].Available from: http://www.bibliotecadigital.ufrgs.br/da.php?nrb=00085410 $8 \& \mid \mathrm{loc}=2012 \& \mathrm{l}=4 \mathrm{f} 371 \mathrm{c} 50790543 \mathrm{fe}$

8. Mello JM, Borges PKO, Muller EV, Grden CRB, Pinheiro FK, Borges WS. Internações por doenças crônicas não transmissíveis do sistema circulatório, sensíveis à Atenção Primária à Saúde. Texto Contexto Enferm. 2017;26(1): e3390015. https://doi.org/10.1590/0104-07072017003390015

9. Rede Nacional de Ensino e Pesquisa -RNP. Rede Universitária de Telemedicina RUTE. [cited 2017 Feb 14]. Available from: https://rute.rnp.br/..

10. Biblioteca Virtual em Saúde - BVS Atenção Primária à Saúde. Telessaúde Brasil Redes - Atenção Primária à Saúde. [cited 2018 Sep 20]. Available from: http://aps.bvs.br/?l=pt_BR.

11. Maldonado JMSV, Marques AB, Cruz A. Telemedicina: desafios à sua difusão no Brasil. Cad Saude Publica. 2016;32 Supl 2:e00155615. https://doi.org/10.1590/0102-311X00155615

12. Netto AV, Tateyama AGP. Avaliação de tecnologia de telemonitoramento e biotelemetria para o cuidado híbrido para o idoso com condição crônica. JHI J Health Inform. 2018;10(4):102-11.

13. Gil AC. Como elaborar projetos de pesquisa. 5. ed. São Paulo: Atlas; 2010.

14. Ministério da Saúde (BR). Programa de Apoio ao Desenvolvimento Institucional do SUS (PROADI-SUS). Brasília, DF; 2018 [cited 2018 Nov 10]. Available from: http://portalms.saude.gov.br/acoes-e-programas/proadi-sus

15. Informa Markets. Feira hospitalar. Hospitalar. 2017 [cited 2018 Feb 3]. Available from: https://www.hospitalar.com/pt/

16. Ministério da Saúde (BR). Entidades de Saúde de Reconhecida Excelência (ESRE). Brasília, DF; 2018 [cited 2018 Nov 10]. Available from: http://portalms.saude.gov.br/acoes-e-programas/ proadi-sus/entidades-de-saude-de-reconhecida-excelencia-esre

17. Agência Nacional de Saúde Suplementar. Sala de Situação. Rio de Janeiro: ANS; 2018. [cited 2018 Nov 10]. Available from: http://www.ans.gov.br/perfil-do-setor/dados-e-indicadores-dosetor/sala-de-situacao

18. Broderick A. The Veterans Health Administration: taking Home Telehealth Services to scale nationally: The Commonwealth Fund case studies in Telehealth adoption. New York: The Commonwealth Fund; 2013 [cited 2017 Aug 21]. Available from: http://www. commonwealthfund.org/ /media/Files/Publications/Case\%20Study/2013/Jan/1657_Broderick_ telehealth_adoption_VHA_case_study.pdf

19. Commission of the European Communities. Communication from the Commission to the European Parliament, the Council, the European Economic and Social Committee and the Committee of the Regions on telemedicine for the benefit of patients, healthcare systems and society. Brussels (BEL); 2008 [cited 2017 Mar 18]. (COM(2008)689final). Available from: https://eur-lex.europa.eu/legal-content/EN/TXT/PDF/?uri=CELEX:52008DC0689\&from=CS

20. Conselho Federal de Medicina. Resolução CFM n 1.643, de 26 de agosto de 2002. Define e disciplina a prestação de serviços através da Telemedicina. Brasília, DF: CFM; 2002 [cited 2018 Dec 10]. Available from: http://www.portalmedico.org.br/resolucoes/ cfm/2002/1643_2002.htm

21. Conselho Federal de Nutrição. Resolução CFN nº 599, de 25 de fevereiro de 2018. Aprova o Código de Ética e de conduta do Nutricionista e dá outras providências. Brasília, DF: CFN; 2018 [cited 2018 Dec 10]. Available from: http://www.cfn.org.br/wp-content/uploads/ resolucoes/Res_599_2018.htm 
22. Conselho Federal de Psicologia. Resolução CFP n 11 , de 11 de maio de 2018. Regulamenta a prestação de serviços psicológicos realizados por meios de tecnologias da informação e da comunicação e revoga a Resolução CFP № 11/2012. Brasília, F: CFP; 2012 [cited 2018 Dec 10]. Available from: https://site.cfp.org.br/wp-content/uploads/2018/05/RESOLUÇÃO-Nº-11-DE11-DE-MAIO-DE-2018.pdf

23. Conselho Federal de Serviço Social. Resolução CFESS Nº 594, de 21 de janeiro de 2011. Altera o Código de Ética do Assistente Social, introduzindo aperfeiçoamentos formais, gramaticais e conceituais em seu texto e garantindo a linguagem de gênero. Brasília, DF: CFSS; 2011 [cited 2018 Dec 10]. Available from: http://cfess.org.br/arquivos/Res594.pdf

24. Conselho Federal de Enfermagem. Resolução COFEN No 564, de 6 de novembro de 2017. Aprova o novo Código de Ética dos Profissionais de Enfermagem. Brasília, DF: COFEN; 2017 [cited 2018 Dec 10]. Available from: http://www.cofen.gov.br/resolucao-cofenno-5642017_59145.html

25. Conselho Federal de Fisioterapia. Estabelece o Código de Ética e Deontologia da Fisioterapia. Resolução COFFITO № 424, de 08 de julho de 2013. Estabelece o Código de Ética e Deontologia da Fisioterapia. Brasília, DF: COFFITP; 2013 [cited 2018 Dec 10]. Available from: https://www.coffito.gov.br/nsite/?p=3187

26. Conselho Federal de Educação Física. Resolução CONFEF № 307, de 09 de novembro de 2015. Dispõe sobre o Código de Ética dos Profissionais de Educação Física registrados no Sistema CONFEF/CREF. Rio de Janeiro: CONFEF; 2015 [cited 2018 Dec 10]. Available from: http://www.confef.org.br/confef/resolucoes/381

27. Instituto Brasileiro de Pesquisa Geográfica e Estatística. Censo 2010. Rio de Janeiro: IBGE, 2010 [cited 2017 16]. Available from: http://censo2010.ibge.gov.br/

28. Ministério da Saúde (BR). Dados de internações do SUS. Brasília, DF; 2017 [cited 2017 Jul 21]. Available from: http://tabnet.datasus.gov.br/cgi/tabcgi.exe?sih/cnv/qiuf.def

29. Mendonça MHM, Matta GC, Gondim R, Giovanella L. Atenção primária à saúde no Brasil: conceitos, práticas e pesquisa. Rio de Janeiro: Fiocruz; 2018.

30. Williams AM, Bhatti UF, Alam HB, Nikolian vC. The role of telemedicine in postoperative care. mHealth. 2018; 4:11. https://doi.org/10.21037/mhealth.2018.04.03

Funding: The publication had financial support from the Fiocruz/Fiotec VPGDI-008-FIO-19-2F project "Challenges for the Brazilian Unified Health System in the National and Global Context of Social, Economic and Technological Transformations"; Carlos Augusto Grabois Gadelha had the research productivity grant from the Conselho Nacional de Desenvolvimento Científico e Tecnológico (CNPq) - Process number 310695/2016-3 - PQ-2 Level.

Authors' Contribution: Study conception and planning: ACP, JMSVM and CAGG. Quantitative data analysis and interpretation: ACP. Writing of the manuscript: ACP, JMSVM and CAGG. Approval of the final version to be published: ACP, JMSVM and CAGG.

Conflict of Interest: The authors declare no conflict of interest. 